\title{
Would an Increase in High-Skilled Immigration in Canada Benefit Workers?
}

\author{
Maxime Fougère, Simon Harvey, and Bruno Rainville \\ Human Resources and Skills Development Canada (HRSDC), Ottawa, ON, Canada K1A OT6 \\ Correspondence should be addressed to Maxime Fougère, maxime.fougere@hrsdc-rhdcc.gc.ca \\ Received 7 December 2010; Revised 25 February 2011; Accepted 3 April 2011 \\ Academic Editor: Magda E. Kandil
}

Copyright () 2011 Maxime Fougère et al. This is an open access article distributed under the Creative Commons Attribution License, which permits unrestricted use, distribution, and reproduction in any medium, provided the original work is properly cited.

This study examines the economic and welfare effects of raising the number of high-skilled immigrants in Canada. It uses a life-cycle applied general equilibrium model with endogenous time allocation decisions between work, education, and leisure. According to the simulation results, raising the number of high-skilled immigrants would boost productive capacity and labour productivity but could lower real GDP per capita. In addition, by raising the supply of high-skilled workers, more high-skilled immigrants would reduce the skill premium and the return to human capital. This in turn would lower incentives for young adults to invest in human capital and have a dampening effect on the domestic supply of skilled workers. Finally, it is found that more high-skilled immigrants would be welfare enhancing for medium- and low-skilled workers but welfare decreasing for high-skilled workers.

\section{Introduction}

With globalization, innovation, and technological changes, the Canadian economy is shifting to more knowledgeintensive activities and higher demand for skilled workers. According to the Labour Force Survey, six out of ten new jobs created between 1987 and 2005 in Canada were in highskilled occupations. At the same time, the Canadian economy faces the challenge of population and workforce ageing, which will inevitably lead to slower labour force growth in the future.

In this context, attracting more high-skilled immigrants is seen as a valuable option to raise labour force growth and meet the increasing demand for high-skilled workers. Like many industrialized countries, Canada already seeks to attract skilled immigrants with its selection of economic immigrants on the basis of a point system (e.g., Australia has a point system with emphasis on skills and the United States of America the $\mathrm{H}-1 \mathrm{~B}$ temporary visa program for high-skilled immigrants). If more high-skilled immigrants can raise the level of GDP in all likelihood, it is, however, not clear that it will necessarily raise real GDP per capita, when lower participation and employment rates of recent skilled immigrants are considered. (The first wave of the Longitudinal Survey on Immigrants to Canada (LSIC, 20002001) shows that new immigrants aged 15-24 have much lower participation (59\%) and employment rates (36\%) than the national average (64.7\% and $57.5 \%$, resp.). New immigrants aged 25-44 also have lower participation (78\%) and employment rates $(50 \%)$ than the national average (86.3\% and $80.6 \%$, resp.); see, e.g., Bouaissa and Pescarus [1].)

A number of studies have examined the overall economic impacts of increasing high-skilled immigration. Recent studies find that selecting more skilled immigrants could be a potential source for the financing of social security in industrialized countries. For example, Storesletten [2] shows that increasing the inflows of high- and mediumskilled immigrant workers would remove the need for fiscal reform in the United States (U.S.). In examining the effects of doubling the number of high-skilled immigrants in the U.S., Europe, and Japan, Fehr et al. [3] conclude that it "comes out on top in terms of its mitigation of future tax hikes".

For Canada, Fougère et al. [4] find that conditional on the recognition of foreign credentials and no integration costs in the Canadian labour market, the positive effects of having 
more high-skilled workers could partly compensate for the negative economic consequences of population ageing. Aydemir and Borjas [5] demonstrate that a 10\% immigrantinduced labour-supply increases lower wages by $3 \%$ to $4 \%$ in Canada, U.S., and Mexico. They also point out that Canada's immigration policy has contributed to narrowing wage inequality by putting downward pressures on wages of high-skilled workers.

The paper is structured as follows. Section 2 describes the model used for the analysis. Section 3 discusses the calibration procedure and demographic shock. Section 4 presents the main results. Section 5 concludes.

\section{The Model}

The model used in this paper is similar to the one in Fougère et al. [6]. It is a dynamic general equilibrium model with an overlapping generations (OLG) structure (a detailed technical description of the model is available upon request), and it is calibrated to represent the Canadian economy.

At each period of time, corresponding to 4 years, there are 15 age groups of adults by skill level and immigration status, structured in an Allais-Samuelson overlapping generations framework. Representative individuals are distributed in three skill levels (i.e., high-, medium-, and low-skilled) and one group who are out of the labour force. The occupational composition of high-skilled workers used in the model is the same as the definition of highly qualified workers used in Laroche [7] and OECD [8]. Vocational trades and occupations usually requiring a college diploma are medium-skilled. Occupations requiring a high school diploma or less and occupations requiring only on-thejob training are low-skilled. (Table 5 provides a detailed description of occupations in the classification of skill levels in the CGE model.)

In the model's overlapping generations structure, there are 8 types of representative individuals (Canadian-born and immigrants by skill level) of 4-year age groups with new cohorts who enter the model at age 17-20 at each time point. They age and remain in the model for 15 periods of 4 years until they die at age 77 . The representative individuals maximize an intertemporal utility function with consumption and leisure as arguments subject to two accumulation conditions: wealth and human capital. Also at any age, each individual allocates a specific proportion of its time endowment toward leisure, work, and human capital formation, and each individual allocates its disposable income in consumption and savings. Savings can be allocated between domestic physical capital ownership titles or government bonds.

In regards to time allocation, representative individuals typically spend a significant proportion of their time in school when young, spend gradually more time in employment as they get older, and gradually increase leisure time as they approach retirement. In the calibration, high-skilled workers spend more time in education when young and more time at work in their core age than medium- and low-skilled workers. For illustration, Figure 1 presents the distribution of time allocation over the working life for

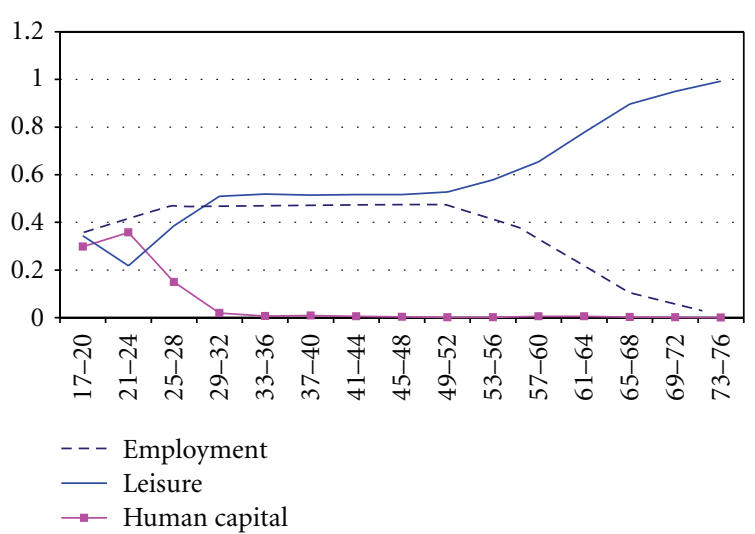

FIGURE 1: Time allocation for high-skilled workers in initial steady state.

high-skilled workers in the initial steady state. (One day in the model is equivalent to 16 hours in a typical 5-day working week (sleeping time is not included). So working $50 \%$ of your time is equivalent to 8 hours of work.) At age 17-20, high-skilled workers allocate more time to education (college and university) and have fewer time allocated to leisure and work. When the cohort reaches age 21-24, more time is spent on education and work at the expense of leisure time. Time spent in education eventually drops and tends to zero as individuals devote more time to work and leisure. Finally, around age 53-56, the preference for leisure begins to increase until full retirement is reached at an older age.

The cost of investing in human capital is the current wage. Investment returns in education and training are a stream of net revenue from future labour supply. Since the return to human capital is the discounted sum of future wage revenues, it is rational to invest in human capital when young and work a little and to invest in physical capital at middle age and older age.

The government collects taxes on labour income, capital income, and consumption expenditures. Government spending is divided into three components: health, education, and other government expenditures. The government distributes social transfers to individuals. The public pension system includes: (1) the Old Age Security (OAS) system, which is modeled as a national transfer program to the elderly and is financed through general taxes from the government, and (2) the Canada/Quebec Pension Plan (CQPP), which is a comprehensive contributory pension plan.

The representative firm produces the unique goods. Its production technology is represented by a Cobb-Douglas function. The firm hires labour by skill and rents physical capital. Labour is a composite factor of 3 skill levels (high, medium, and low) represented by a constant elasticity of substitution function. The investment technology is represented by a constant elasticity of substitution (CES) function.

The model assumes perfectly competitive markets and agents with perfect foresight. Bonds and physical capital ownerships are considered perfect substitutes; hence, total supply of assets must equal total demand. 


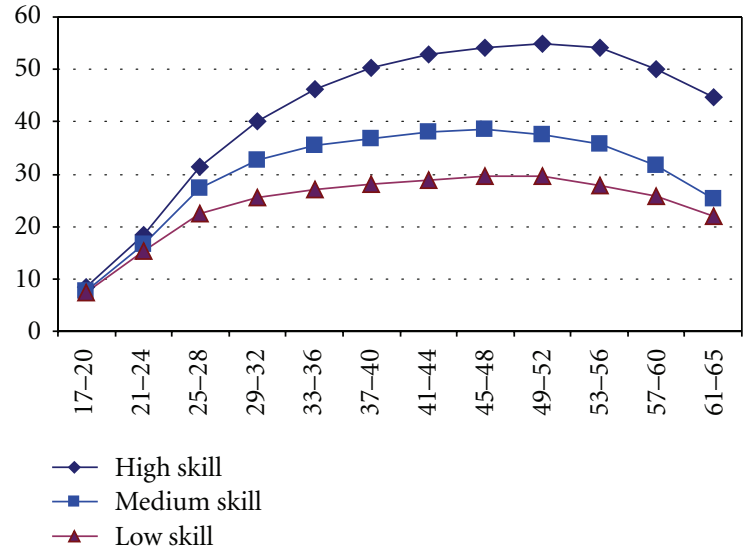

Figure 2: Earnings by skill level and age for Canadian-born individuals.

\section{Calibration Procedure, Parameters, and Economic Welfare}

Since the simulation results depend greatly on the parameter values of the behavioural functions, the calibration procedure is an important and delicate task. The computable general equilibrium (CGE) model must first generate an initial equilibrium in a dynamic framework, to replicate the stylised facts present in the data. The initial equilibrium is in fact a steady state that repeats every period with a population structure assumed to remain unchanged. A demographic shift is then introduced to the steady state to capture the composition of the population in 2002 and the demographic projection up to 2046. Since the population composition of 2002 is the result of changes in the birth rate and life expectancy that occurred in the past, it is necessary to begin the demographic shock in 1946. Changes in the birth rate are used to replicate the old-age dependency ratio observed and projected up to 2046. After 2046, we assume that the birth rate gradually returns to its natural replacement level.

3.1. Earnings by Skill. The distribution of earnings in the initial steady state differs substantially by skill level, immigration status, and age. The calibration is based on information from the 2001 Census. Figure 2 presents the distribution of earnings by age for Canadian-born individuals. As expected, those with higher skill earn more because they are more productive. The age-earnings profile for high-skilled workers also has a steeper slope. The earnings level stabilises around age 49-52 and begins to decline after age 56 . In comparison, the age-earnings profile for medium and low-skilled workers is much lower across all ages, peaks earlier and declines at age 49-52.

3.2. Immigrants versus Nonimmigrants. Table 1 reports the distribution of recent immigrants (been in Canada for 5 years or less), other immigrants (been in Canada for more than 5 years), and Canadian-born workers by skill levels as calibrated in the initial steady state. The distribution of Canadian-born workers by skills has been fairly stable
TABLE 1: Skill share of immigrants and nonimmigrant population.

\begin{tabular}{lcccc}
\hline Skill level & High & Medium & Low & Unattached \\
\hline Canadian-born & 0.267 & 0.222 & 0.293 & 0.219 \\
\hline $\begin{array}{l}\text { Recent } \\
\text { immigrants }\end{array}$ & 0.240 & 0.130 & 0.280 & 0.350 \\
\hline $\begin{array}{l}\text { Other } \\
\text { immigrants }\end{array}$ & 0.156 & 0.136 & 0.302 & 0.406 \\
\hline
\end{tabular}

in Canada over the past 10 years. For recent immigrants, the proportion of skilled immigrants has changed radically over the 1990s. According to the 2001 Census, 26.7\% (24\%) of Canadian-born (recent immigrants) are highskilled workers, 22.2\% (13\%) medium-skilled, and 29.3\% (28\%) low-skilled. In addition, 21.9\% (35\%) are unattached individuals.

Finally, the skill distribution of immigrants who have been in Canada for more than 5 years is calibrated on the 1996 Census. For immigrants who came to Canada earlier, $15.6 \%$ are high-skilled, $13.6 \%$ are medium-skilled, $30.2 \%$ are low-skilled, and $40.6 \%$ are unattached to the labour market.

3.3. Behavioural Parameters. Table 2 reports key behavioural and government program parameter values. The value of the intertemporal elasticity of substitution is 0.9 and the value of the intratemporal elasticity of substitution between consumption and leisure is 0.8. These values are similar to those used by Altig et al. [9], Kotlikoff et al. [10], and Baylor [11]. The CPP/QPP pension replacement rate is 0.2 . The elasticity of substitution for labour demand across qualification is set to 1.5. This is based on a survey of recent studies who estimated long-run elasticity of substitution between more educated and less educated workers (these studies are those of Ciccone and Peri [12], Krusell et al. [13], Caselli and Coleman [14], and Katz and Murphy [15]). The elasticity of time allocated to the production of human capital is based on Fougère and Mérette $[16,17]$ and Heckman et al. [18] (this combines the sum of the elasticity of time allocated to the production of human capital and of the elasticity of human capital already acquired to the production of human capital. Heckman et al. [18] have estimated the value of the sum to equal 1.8).

3.4. Measuring Lifetime Economic Welfare by Cohort and Level of Qualification. We calculate the impact of population ageing and increased skilled immigration on lifetime economic welfare by cohort and level of qualification. First, to define lifetime utility in the model, we assume that Canadian and foreign-born individuals optimise a CES type intertemporal utility function of consumption and time allocation subject to lifetime income and time constraint. The household's optimisation problem consists of choosing the consumption and savings pattern over the lifecycle, as well as the time allocation between working, education, and leisure. Time spent in education correspond to human capital investment. Human capital gains also raise effective labour supply and the quality of leisure. For each of the 8 different types of representative adults (Canadian-born and 
TABLE 2: Behavioural and government program parameters.

\begin{tabular}{lc}
\hline & Value \\
\hline Intertemporal elasticity of substitution & 0.9 \\
Intratemporal elasticity of substitution & 0.8 \\
Ratio of CPP/QPP pension replacement rate & 0.2 \\
Elasticity of time allocated to the production & 0.7 \\
of human capital & \\
Elasticity of substitution for labour demand & 1.5 \\
across qualification & 0.3 \\
Production share of physical capital & 0.04 (per year) \\
Rate of interest & 0.05 (per year) \\
Depreciation rate of physical capital & 0.21 \\
Government expenditures/GDP & 0.0842 \\
Government debt/GDP & 0.318 \\
Labour income tax rate & 0.352 \\
Capital income tax rate & 0.11 \\
Consumption tax rate &
\end{tabular}

immigrants are distributed into four skill levels (high-skilled, medium-skilled, low-skilled, and out of the labour force)), the intertemporal utility function takes the following form:

$$
\begin{aligned}
& U_{\text {qual,nat }} \\
& =\frac{1}{1-\sigma} \sum_{g=17}^{76}\left(\frac{1}{1+\rho}\right)^{g} \\
& \quad \times\left(C_{\text {qual,nat }, g, t+g-1}^{1-\theta}+\phi_{\text {qual,nat }, g} \mathrm{LA}_{\text {qual,nat }, g, t+g-1}^{\theta}\right)^{(1-\sigma) /(1-\theta),} \\
& \quad 0<\theta<1,
\end{aligned}
$$

$C_{\text {qual,nat, },, t}$ and $\mathrm{LA}_{\text {qual,nat }, g, t}$ are, respectively, consumption and leisure activity of an individual of qualification qual, nationality (native or foreign-born) nat, age group $g$ at time $t ; \rho$ the pure rate of time preference; $\sigma$ the inverse of the intertemporal elasticity of substitution; $\theta$ the inverse of the intratemporal elasticity of substitution between consumption and leisure activity; $\phi_{\text {qual,nat }, g}$ the leisure activity preference parameter, which is higher for the lower qualification.

Similar to Auerbach and Kotlikoff [19], the welfare measure is calculated as follows. First, according to (1), we calculate the level of utility $U_{\text {qual, } t}^{I}$ before the demographic shock by cohort and level of qualification, which depends on life-time consumption and leisure activity, where $I$ indicates the level of utility in the initial steady state, for cohort $t$ (a cohort is defined by its year of entry in the labour market at 17 years old), and level of qualification qual. Next, we recalculate utility levels by cohort and level of qualification, $U_{\text {qual }, t}^{F}$ and report the percentage difference, $\left(U_{\text {qual }, t}^{F}-U_{\text {qual }, t}^{I}\right) / U_{\text {qual }, t}^{I}$. The same calculation is made to evaluate the economic welfare effect of changes in immigration.

\section{Simulation Results}

We use the dynamic computable general equilibrium model to simulate two scenarios: the benchmark scenario, which factors in population ageing with our baseline assumption regarding immigration, and an alternative scenario which also factors in population ageing but with more immigration. In the benchmark scenario, we assume that the proportion of recent immigrants (permanent residents) represents $0.75 \%$ of the population each year. Population ageing is incorporated in the model in a way that the structure of the population reproduces historical and projected elderly dependency ratio (the population $65+$ as a proportion of the population 15-64), which is based on the Human Resources and Social Development Canada (HRSDC) Canadian Occupational Projection System-Reference scenario (2006). The benchmark scenario also assumes that, beginning in 2002, the skill distribution of future immigrants is the same as in the 2001 Census.

In the alternative scenario with more immigration, we examine the marginal effect of increasing the proportion of recent immigrants from $0.75 \%$ to $1 \%$ of the population, starting in 2002, and assume that the additional $0.25 \%$ of immigrants is composed of only high-skilled workers (a raise of the immigration target to $1.0 \%$ of the population has often been suggested by policy makers and some Canadian Think Tanks as a potential solution to the ageing of the Canadian population (see, e.g., $[20,21])$ ). This immigration shock, an extra flow of high-skilled immigrants, gradually raises the supply of high-skilled workers in the labour market over time.

Table 3 shows the results on selected key macroeconomic and key labour market indicators, respectively. Table 4 presents the impact on time allocated to education by cohort of high-skilled workers. Figure 3 looks at lifetime economic welfare and lifetime consumption by cohort for high-, medium-, and low-skilled workers. The results are also presented in percentage point difference relative to the benchmark scenario, with the exception of Table 4 where the level and per cent difference compared to the benchmark scenario are presented.

In Table 3, the results show that an increase in effective labour supply due to more skilled immigrants (3.7 p.p. in 2050 ) over the long-run raises real GDP (3.1 p.p. in 2050), real GDP per labour supply (0.5 p.p. in 2050) but not real GDP per capita ( -1.5 p.p. in 2050). Two factors explain this decrease in real GDP per capita. First, the rise in effective labour supply is initially restricted by lower employment rates for young high-skilled immigrants and more time allocated in postsecondary education. This result is consistent with recent evidence showing that many immigrants experience difficulties getting jobs for which they are qualified because their academic credentials or work experience obtained outside Canada are not recognized. Many of them respond by enrolling in postsecondary education in their first years in Canada to improve their chances of finding a job. (Adamuti-Trache and Sweet [22] show that immigrants with high prior education level, especially university degrees, are more likely to participate in postsecondary education 
TABle 3: Impact of increases in high-skilled immigration on selected key macroeconomic indicators (percentage point difference relative to the benchmark scenario).

\begin{tabular}{|c|c|c|c|c|c|c|}
\hline & 2006 & 2010 & 2018 & 2026 & 2034 & 2050 \\
\hline Real GDP & 0.0 & 0.0 & 0.1 & 0.4 & 1.0 & 3.1 \\
\hline $\begin{array}{l}\text { Real GDP per } \\
\text { labour supply }\end{array}$ & 0.1 & 0.2 & 0.3 & 0.3 & 0.3 & 0.5 \\
\hline $\begin{array}{l}\text { Real GDP per } \\
\text { capita }\end{array}$ & 0.0 & -0.1 & -0.4 & -0.8 & -1.1 & -1.5 \\
\hline $\begin{array}{l}\text { Effective labour } \\
\text { supply }\end{array}$ & 0.0 & 0.0 & 0.2 & 0.5 & 1.3 & 3.7 \\
\hline $\begin{array}{l}\text { Effective labour } \\
\text { supply per capita }\end{array}$ & 0.0 & -0.1 & -0.3 & -0.6 & -0.6 & -0.2 \\
\hline $\begin{array}{l}\text { Physical capital } \\
\text { stock }\end{array}$ & 0.0 & 0.0 & 0.1 & 0.2 & 0.5 & 2.1 \\
\hline $\begin{array}{l}\text { Physical capital } \\
\text { stock per capita }\end{array}$ & 0.0 & -0.1 & -0.4 & -1.2 & -2.0 & -4.2 \\
\hline $\begin{array}{l}\text { Capital-labour } \\
\text { ratio }\end{array}$ & 0.0 & 0.0 & -0.1 & -0.5 & -1.2 & -4.2 \\
\hline $\begin{array}{l}\text { Consumption per } \\
\text { capita }\end{array}$ & 0.0 & -0.1 & -0.4 & -0.9 & -1.4 & -1.7 \\
\hline $\begin{array}{l}\text { Wage rate-all } \\
\text { workers }\end{array}$ & 0.0 & 0.0 & 0.0 & -0.1 & -0.2 & -0.9 \\
\hline $\begin{array}{l}\text { Wage rate-high- } \\
\text { skilled }\end{array}$ & -0.3 & -0.8 & -1.9 & -3.3 & -4.9 & -8.0 \\
\hline $\begin{array}{l}\text { Wage rate- } \\
\text { medium-skilled }\end{array}$ & 0.1 & 0.1 & 0.3 & 0.6 & 0.8 & 0.6 \\
\hline $\begin{array}{l}\text { Wage } \\
\text { rate-low-skilled }\end{array}$ & 0.1 & 0.2 & 0.5 & 0.9 & 1.3 & 1.3 \\
\hline $\begin{array}{l}\text { Skill premium } \\
\text { (HS versus MS) }\end{array}$ & -0.4 & -0.9 & -2.2 & -3.9 & -5.8 & -8.6 \\
\hline $\begin{array}{l}\text { Skill premium } \\
\text { (HS versus LS) }\end{array}$ & -0.4 & -1.0 & -2.4 & -4.2 & -6.2 & -9.3 \\
\hline $\begin{array}{l}\text { Labour income } \\
\text { tax rate }\end{array}$ & 0.0 & -0.1 & -0.1 & -0.2 & -0.4 & -1.5 \\
\hline
\end{tabular}

in Canada. Also, results from the first wave (2000-2001) of the Longitudinal Survey on Immigrants in Canada (LSIC) demonstrate that new immigrants aged 15-24 have lower participation rate $(59 \%)$ and employment rate $(36 \%)$ than the national average $(64.7 \%$ and $57.5 \%$, resp.) aged $15-24$.)

Second, there is a decrease in physical capital accumulation as physical capital per capita constantly decreases to reach $-4.2 \%$ in 2050 . The larger flows of young highskilled workers work less as they invest more in education, earn less, and therefore save less than other workers. This has a negative effect on savings and the accumulation of physical capital through assets and bonds. In addition, the excess supply of high-skilled workers strongly decreases their wage rate $(-8.0$ p.p. in 2050). This result is consistent with Borjas [23] who found that a foreign student influx into a particular doctoral field had a significant negative impact on the earnings of doctorates in that field who graduated roughly at the same time. (More specifically, using the Survey of Earned Doctorates and the Survey of Doctoral Recipients, Borjas [23] found that a $10 \%$ immigrationinduced increase in the supply of doctorates in the U.S.

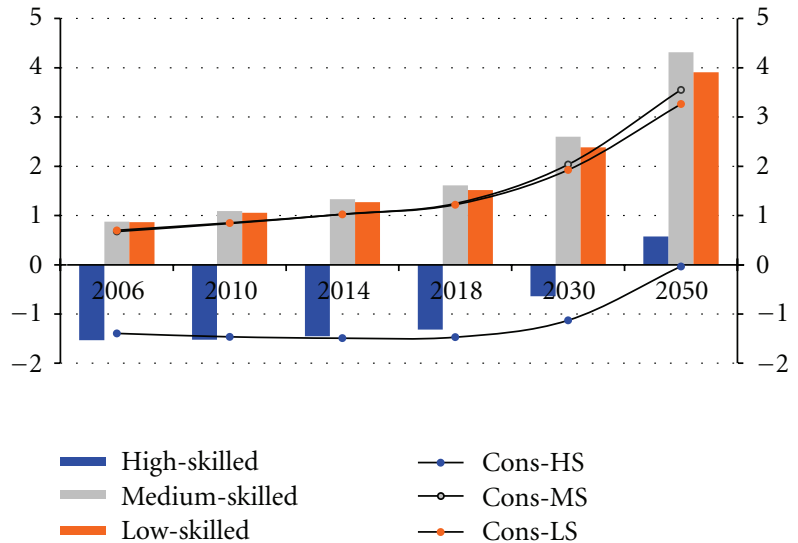

FIGURE 3: Impact of an increase in high-skilled immigration on lifetime economic-welfare and consumption by cohort and skill level (percent point difference relative to the benchmark scenario).

TABLE 4: Change in weekly hours allocated to education by cohorts of young high-skilled workers (level and per cent difference* relative to the benchmark scenario).

\begin{tabular}{lcccccc}
\hline & 2006 & 2010 & 2014 & 2018 & 2030 & 2050 \\
\hline $17-20$ & -1.2 & -1.4 & -1.7 & -2.0 & -2.1 & 0.5 \\
years old & $(-4.5)$ & $(-5.7)$ & $(-6.7)$ & $(-7.7)$ & $(-8.3)$ & $(2.4)$ \\
\hline $21-24$ & -0.3 & -0.6 & -0.9 & -1.2 & -1.6 & -0.2 \\
years old & $(-1.2)$ & $(-2.1)$ & $(-3.0)$ & $(-4.0)$ & $(-5.3)$ & $(0.7)$ \\
\hline $25-28$ & -0.4 & -0.5 & -0.6 & -0.7 & -0.6 & -0.8 \\
years old & $(-3.4)$ & $(-4.1)$ & $(-5.3)$ & $(-5.3)$ & $(-4.4)$ & $(-5.9)$ \\
\hline
\end{tabular}

${ }^{*}$ The per cent difference is shown in brackets.

would lower the wage of competing workers by about $3 \%$.) It also creates a relative scarcity of both medium- and lowskilled workers. As a result, it boosts wage rates of mediumand low-skilled workers $(0.6 \%$ and $1.3 \%$, resp., in 2050). The negative effect on wage rate of high-skilled workers decreases their skill premium versus medium- $(-8.6$ p.p. in $2050)$ and low-skilled workers ( -9.3 p.p. in 2050), which in turn lowers incentives to invest in education and further limit the expansion of effective labour supply. According to Table 4, time allocated to education decreases steadily for young high-skilled workers over the medium and long-run. For example, young high-skilled aged 17-20 years reduce time allocated to education by 2.0 hours per week $(-7.7 \%)$ in 2018 and 2.1 hours per week $(-8.3 \%)$ in 2030 , while young high-skilled aged 21-24 years decrease time allocated to education by 1.6 hours per week $(-5.3 \%)$ in 2030 and 0.2 hours per week $(-0.7 \%)$ in 2050.

Finally, when we look at the impact of lifetime economic welfare by cohort (Figure 3), high-skilled are much worse off compared to medium- and low-skilled workers. However, despite a negative impact on lifetime consumption throughout the simulation, they eventually benefit from a small increase in economic welfare, thanks to the increase in lifetime leisure. Here, the strong decrease in real wage rates of high-skilled workers is responsible for the negative impact on lifetime consumption. On the other hand, medium- and 
TABLE 5: Classification of skill levels in the CGE model.

\begin{tabular}{|c|c|}
\hline \multirow{9}{*}{ High skill* } & National Occupational Classification Matrix 2001 (NOC) \\
\hline & Skill level 0 (managers), \\
\hline & Skill level A and \\
\hline & Occupations found in skill level B \\
\hline & $\begin{array}{l}\text { (i) Major group 12, skilled administration and business occupations, except minor group 124, secretaries, } \\
\text { recorders, and transcriptionists. }\end{array}$ \\
\hline & (ii) Major group 22, technical occupations related to natural and applied sciences. \\
\hline & (iii) Major group 32, technical and skilled occupations in health. \\
\hline & (iv) Major group 42, paraprofessional occupations in law, social services, education, and religion. \\
\hline & (v) Major group 52, technical and skilled occupations in art, culture, recreation, and sport. \\
\hline \multirow{7}{*}{ Medium skill } & National Occupational Classification Matrix 2001 (NOC) \\
\hline & Occupations found in skill level B \\
\hline & (i) Minor group 124, secretaries, recorders, and transcriptionists. \\
\hline & (ii) Major group 62, skilled sales and service occupations. \\
\hline & (iii) Major group 72/73, trade and skilled transport and equipment operators. \\
\hline & (iv) Major group 82, skilled occupations in primary industry. \\
\hline & (v) Major group 92, processing, manufacturing and utilities supervisors, and skilled operators. \\
\hline \multirow{2}{*}{ Low skill } & National Occupational Classification Matrix 2001 (NOC) \\
\hline & skill level C and Skill level D \\
\hline
\end{tabular}

* High skill, same as the one proposed by CETECH based on the OECD (2000) definition (see Laroche [7] and OECD [8]).

low-skilled workers are better off, benefiting mostly from an increase in lifetime consumption. Figure 3 shows that only medium- and low-skilled workers see their economic welfare increasing significantly.

\section{Conclusion}

According to the paper, an immigration policy targeted towards high-skilled (highly productive) immigrant workers increases labour quality, boosts labour productivity, and raises the productive capacity of the Canadian economy. However, although total real GDP increases, real GDP per capita decreases. This is mostly because young highskilled immigrants have lower labour force participation rate initially and low savings rate, as they normally spend more time in postsecondary education at the beginning of their working life, compared with lower-skilled workers. This in turn has a negative impact on labour supply (hours of work) and physical capital accumulation.

Decisions to invest in human capital depend on expected future wages. Another finding from the model results and supported by Borjas [23] is that since a larger flow of young high-skilled immigrants raises the total supply of high-skilled in the economy, it also reduces wages for highskilled workers, the skill premium, and the return to human capital. Therefore, over the life cycle, according to our model findings, if agents are rational, the reduction in the skill premium would reduce incentives for youth to invest in postsecondary education.

Finally, this policy reduces earnings inequality and inequality in economic welfare mainly by making highskilled workers worse off, rather than by raising income for lower skilled workers. This result finding is also supported by Aydemir and Borjas [5] who found that Canada's immigration policy in Canada has led to a reduction in earnings inequality through lower high-skilled wages.

\section{Acknowledgments}

The views expressed in this paper are solely those of the authors and do not necessarily reflect the views of HRSDC. The authors wish to thank Nabil Annabi for his contribution to the endogenous time-allocation CGE model, Marcel Mérette for technical advices, and Gilles Bérubé, Cliff Halliwell, and one anonymous referee for useful comments.

\section{References}

[1] M. Bouaissa and C. Pescarus, "How Well do Recent Immigrants on the Canadian Labour Market?" HRSDC Policy Research Directorate working paper no. SP-921-10-09E, 2009.

[2] K. Storesletten, "Sustaining fiscal policy through immigration," Journal of Political Economy, vol. 108, no. 2, pp. 300-323, 2000.

[3] Fehr, Jokisch, and L. J. Kotlikoff, "The Role of Immigration in Dealing with Developed World's Demographic Transition," NBER working paper no. W10512, 2004.

[4] M. Fougère, S. Harvey, J. Mercenier, and M. Mérette, "Population Ageing, High-Skilled Immigrants and Productivity," HRSDC-IC-SSHRC Skills Research Initiative Working Paper no. 2005 A-07, 2005.

[5] A. Aydemir and G. J. Borjas, "A Comparative Analysis of the Labour Market Impact of International Migration: Canada, Mexico, and the Unites States," NBER Working Paper no. 12327, June 2006.

[6] M. Fougère, S. Harvey, Y. Lan, A. Léonard, and B. Rainville, "Incentives for early retirement in Canada: an analysis with 
a dynamic life-cycle CGE model," in Retirement Policy Issues in Canada, John Deutsch Institute for the Study of Economic Policy, M. G. Abbott, C. M. Beach, R. W. Boadway, and J. G. MacKinnon, Eds., McGill-Queen's University Press, 2009.

[7] G. Laroche, "L'approche par profession de l'emploi hautement qualifié," Mimeo CETECH, 2000.

[8] OECD, "Knowledge Management in the learning society," Paris, France, 2000.

[9] D. Altig, A. Auerbach, L. J. Kotlikoff, K. Smetters, and J. Walliser, "Simulating U.S. tax reform," NBER Working Paper no. $6248,1997$.

[10] L. Kotlikoff, K. Smetters, and J. Walliser, "Privatizing social security: a simulation study," in Pension System: From Crisis to Reform, K. S. Hebbel, Ed., The World Bank, Washington, DC, USA, 1999.

[11] M. Baylor, "Government debt, taxation, and the economic dynamics of population ageing," in Proceedings of the Annual Meeting of the CEA, Mimeo, Hamilton, Canada, May 2005.

[12] A. Ciccone and G. Peri, "Long-run substitutability between more and less educated workers: evidence from U.S. states, 1950-1990," Review of Economics and Statistics, vol. 87, no. 4, pp. 652-663, 2005.

[13] P. Krusell, L. E. Ohanian, J. V. Ríos-Rull, and G. L. Violante, "Capital-skill complementarity and inequality: a macroeconomic analysis," Econometrica, vol. 68, no. 5, pp. 1029-1053, 2000.

[14] F. Caselli and W. Coleman, "The World Technology Frontier," NBER working paper no. 7904, 2000.

[15] L. F. Katz and K. M. Murphy, "Changes in relative wages, 1963-1987: supply and demand factors," Quarterly Journal of Economics, vol. 107, no. 1, pp. 35-78, 1992.

[16] M. Fougère and M. Mérette, "Population ageing and economic growth in seven OECD countries," Economic Modelling, vol. 16, no. 3, pp. 411-427, 1999.

[17] M. Fougère and M. Mérette, "Population aging, intergenerational equity and growth: an analysis with an endogenous growth overlapping generations model," in Using Dynamic General Equilibrium Models for Policy Analysis, G. Harrison, S. E. H. Jensen, L. H. Pedersen, and T. Rutherford, Eds., North Holland, Amsterdam, The Netherlands, 2000.

[18] J. J. Heckman, L. Lochner, and C. Taber, "Explaining rising wage inequality: explorations with a dynamic general equilibrium model of labor earnings with heterogeneous agents," Review of Economic Dynamics, vol. 1, no. 1, pp. 1-58, 1998.

[19] A. J. Auerbach and L. J. Kotlikoff, Dynamic Fiscal Policy, Cambridge University Press, Cambridge, UK, 1987.

[20] Y. Guillemette and W. B. P. Robson, No Elixir of Youth: Immigration Cannot Keep Canada Young, C. D. Howe Institute Backgrounder, no. 96, C. D. Howe Institute, Toronto, Canada, 2006.

[21] RBC Financial Group, "The diversity advantage: a case for Canada's 21st century economy," in Proceedings of the 10th International Metropolis Conference, Toronto, Canada, October 2005.

[22] M. Adamuti-Trache and R. Sweet, "Adult immigrant's participation in Canadian education and training," Canadian Journal for the Study of Adult Education, vol. 22, no. 2, pp. 1-26, 2010.

[23] G. J. Borjas, "The labor-market impact of high-skill immigration," American Economic Review, vol. 95, no. 2, pp. 56-60, 2005. 


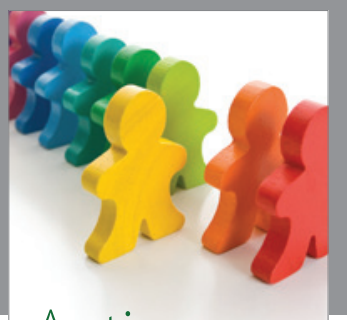

Autism

Research and Treatment
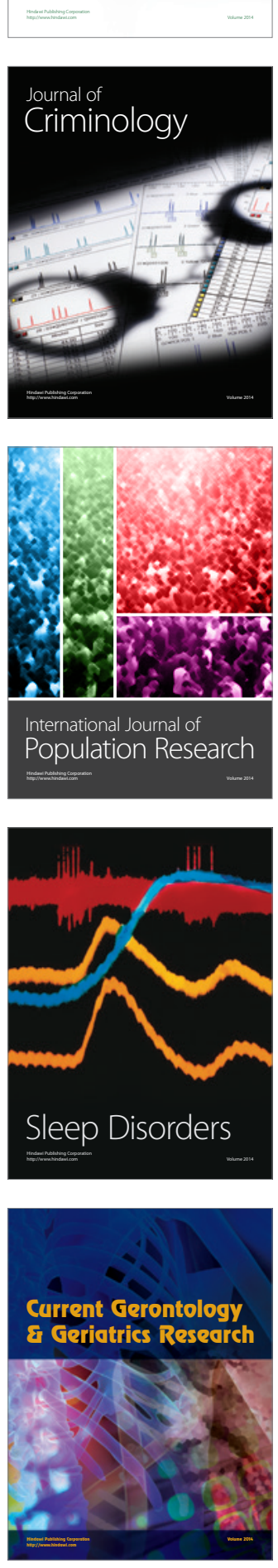
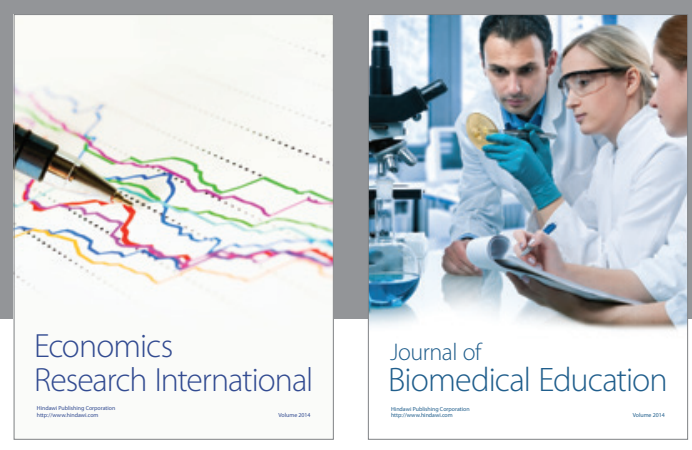

Journal of

Biomedical Education

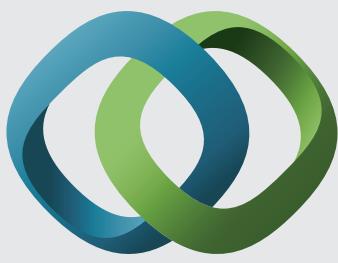

\section{Hindawi}

Submit your manuscripts at

http://www.hindawi.com
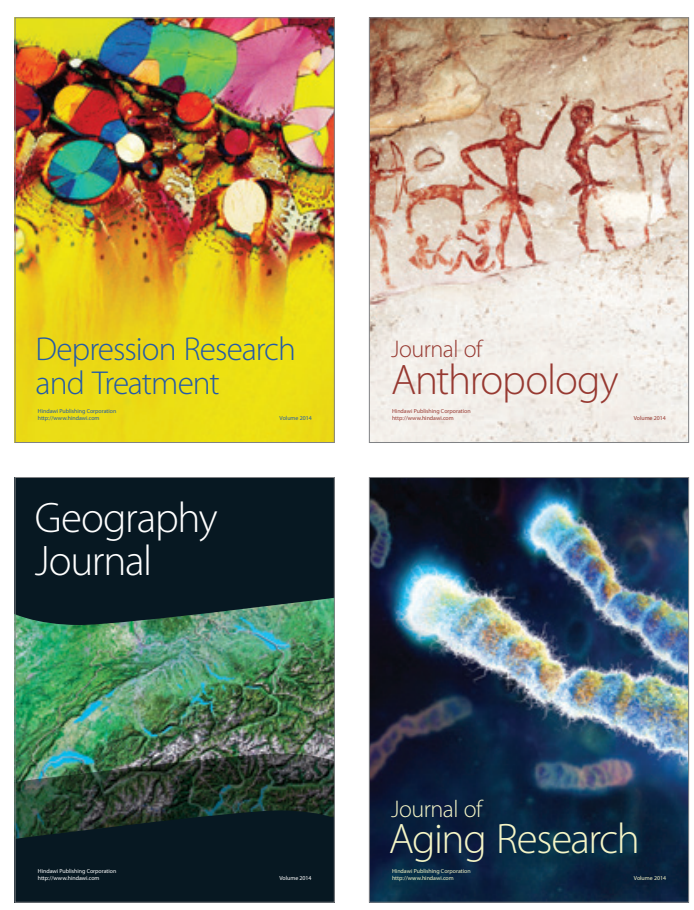

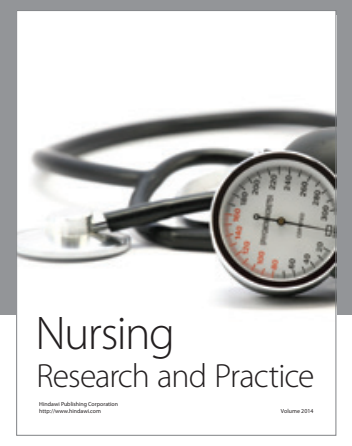

Nursing

Research and Practice

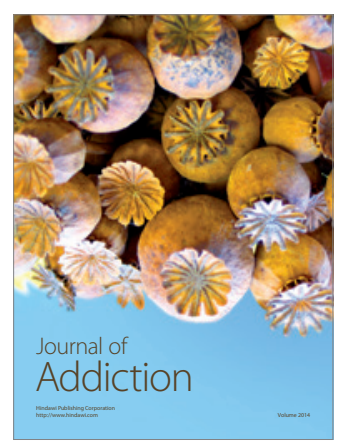

Child Development

Research

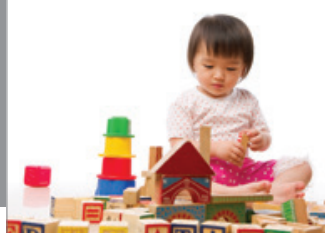

迥
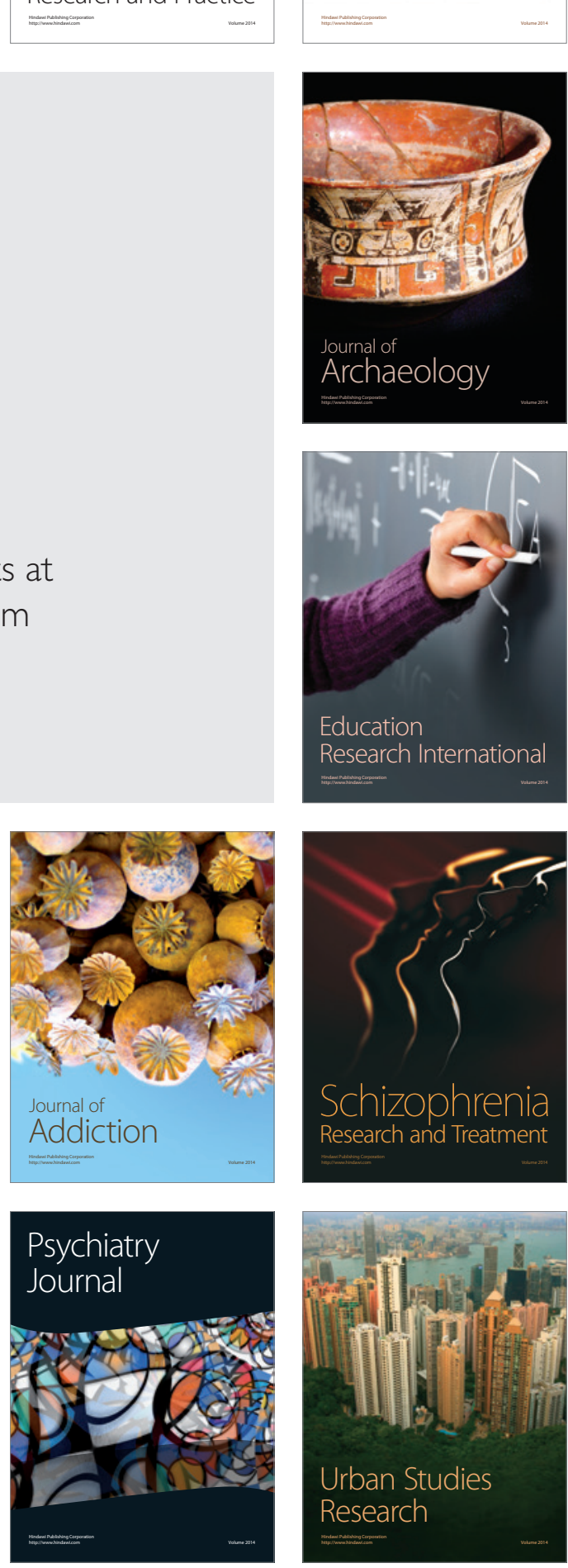